\title{
Waste incineration in rotary kilns: a new simulation combustion tool to support design and technical change
}

Waste Management \& Research 0(0) 1-12

(C) The Author(s) 2013

Reprints and permissions:

sagepub.co.uk/journalsPermissions.nav DOI: 10.1177/0734242X13484187

wmr.sagepub.com

(S)AGE

\section{Francesco Lombardi1, Emanuele Lategano1, Stefano Cordiner ${ }^{2}$ and Vincenzo Torretta ${ }^{3}$}

\begin{abstract}
This article presents a tool based on a simplified model developed for the combustion processes in a rotary kiln incinerator (slightly inclined rotating primary combustion chamber). The model was developed with the aim of supporting the design phase of the incinerator combustion chamber and, at the same time, of investigating possible technical changes in existing plants in order to optimise the combustion process and the dimension of the rotary kiln (length, diameter) as a function of the characteristics of the fed waste. The tool has been applied and the obtained results compared with a real incineration plant operating on healthcare waste located in Rome (Italy). The mass and thermal balances were taken into account, together with kinetic parameters for the combustion of the specific waste stream. The mass balance considered only the major mass components (carbon, hydrogen, oxygen, nitrogen and sulphur). The measured external temperatures appear to be in good agreement with the simulated results. A sensitivity analysis of the plant under different operating conditions was carried out using different input flow rates and excess air ratios, and an assessment was made of the refractory and insulator properties of the kiln's behaviour. Some of the simulated results were used during the periodical maintenance to improve the refractory characteristics in order to reduce the fret and corrosion process.
\end{abstract}

\section{Keywords}

Waste combustion, simulation model, rotary kiln, thermal and mass balances, refractory

\section{Introduction}

Solid waste production has increased with the growth of national economies and improvements in living standards. Efficient waste treatment solutions have to be developed to avoid critical situations relating to their disposal. In accordance with European Union (EU) guidelines (Torretta et al., 2013), it is absolutely essential to reduce waste, in terms of volume and materials, and recover energy. In this context, given the continuous increase in the energy content of waste (i.e. plastic, paper and cardboard), the incineration process may be an efficient, short-term solution for many of the open issues that relate to waste management, such as energy production, hygienisation, reduction of volume (the remaining mass accounts for $15-30 \%$ of the input waste) and production of non-hazardous residues (bottom ash, 10-25\% of the input waste) that might be reused. The small amount of hazardous residues (fly ash, $5-10 \%$ of the input waste) must be disposed of in sanitary landfills (Amutha Rani et al., 2008) in order to minimize the risk to the environment and public health (Di Mauro et al., 2012).

As far as healthcare waste is concerned, the advantages of incineration become more evident: this particular waste flow may have a high pathogen and bacterial content, which requires incineration in order to reduce its danger and ensure safe disposal, in compliance with EU guidelines. The thermal treatment of this waste is usually carried out in specific plants, in which energy is recovered, where the combustion chamber is a rotary kiln; for the heterogeneity of the feed waste, the rotary kiln is the most appropriate solution for the complete incineration and stabilisation of healthcare waste.

In this study, a tool based on a simplified model to simulate the behaviour of the combustion system has been developed, with two main objectives: (i) to improve predictive capabilities as design tools during the planning phase and (ii) to identify the potential revamping activities of the existing plants, evaluating their effects, a priori.

Heterogeneous combustion in the kiln is a key point in the optimal management of an incinerator, and also leads to the control of emissions (Shin and Choi, 2000). The waste size and composition is, by definition, very heterogeneous; this is even more true for

1Department of Civil Engineering, University of Rome Tor Vergata, Rome, Italy

${ }^{2}$ Department of Mechanical Engineering, University of Rome Tor Vergata, Rome, Italy

3Department of Science and High Technology, Insubria University of Varese, Varese, Italy

\section{Corresponding author:}

Vincenzo Torretta, Department of Science and High Technology, Insubria University of Varese, Via G.B. Vico, 46, I-21100 Varese, Italy. Email: vincenzo.torrettaduninsubria.it 


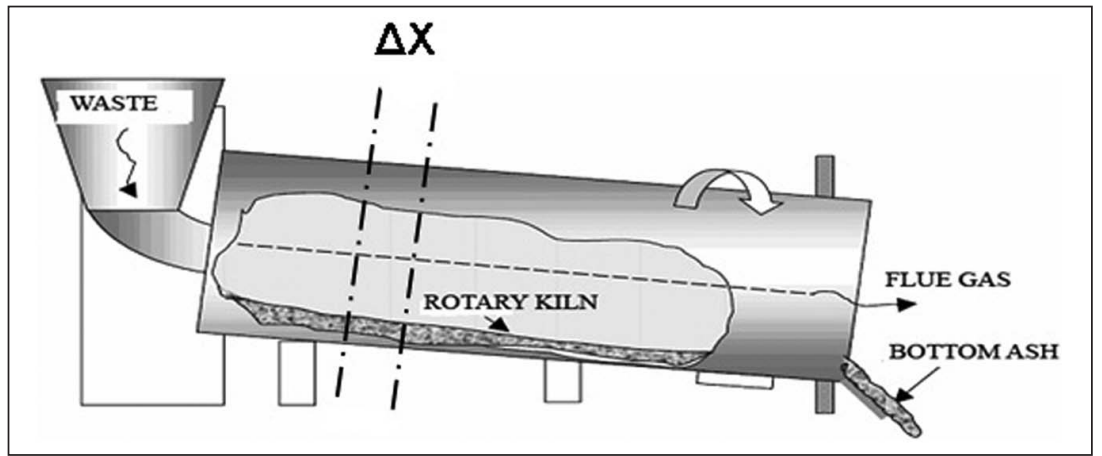

Figure 1. Rotary kiln combustion chamber.

healthcare waste, which comes from different origins: hospitals, biological and chemical laboratories, and expired medicines. This is the most critical reason for the unstable operation of the healthcare waste incinerator. Waste combustion is also influenced by a large number of different, albeit connected, factors; in addition to fuel composition, the air supply rate and the heat transfer between the solid and gaseous phases play an important role. In this model, combustion was investigated using one-dimensional experiments, without considering the transition to fully operational conditions. The combustion was modelled mathematically using a model based on the finite volume method. It is therefore essential to model the solid's axial motion while developing a reaction engineering model of the kiln (Mujumdar and Ranada, 2006).

Waste combustion was developed, taking into consideration three different steps: evaporation of moisture, pyrolysis, and combustion of the solid and gaseous phase. The most suitable kinetic constants were tested and used for every step (Fjellerup et al., 2005, Huai et al., 2008, Yang et al., 2003). The model can describe the effects of the primary air supply rate, the calorific value, the geometry of the combustion chamber, and the refractory and insulator material. A similar model for tyre devolatilisation was developed (Ndiaye et al., 2008). In the technical literature there are models that simulate the combustion of healthcare waste that take place in rotary kiln combustion chambers (Niessen, 2010) that better describe the phenomenon.

The combustion modelling was focussed only on macrocomponents [carbon $(\mathrm{C})$, hydrogen $(\mathrm{H})$, oxygen $(\mathrm{O})$, nitrogen (N) and sulphur (S)] and it results governed solely by the kinetics of reaction, assuming that there are no other limiting conditions (i.e. imperfect mixing characteristics in the gas phase, the tumbling and sliding movement of the solids, and their surface renewal, etc.).

The tool has been applied and improved using input data that referred to a full-scale rotary kiln healthcare waste incinerator located in Rome (Italy). The obtained results were compared with the measured value of the full-scale incinerator. The daily capacity of the plant is around $80-100$ tonnes, operating on two parallel lines.

The test was carried out, comparing the inside and outside temperatures obtained from the model with the real temperatures measured and estimated, by means of calculations in the real plant. The real (industrial)-scale rotary kiln plant is used by councils and industrial plants. It has two chambers: a primary one and a secondary one. The primary chamber in a rotary kiln incinerator consists of an inclined refractory lined cylindrical tube. Movement of the cylinder around its axis helps to maintain the movement of waste. In the primary chamber, the solid fraction is converted into gases, by means of volatilization, destructive distillation and partial combustion reactions. The secondary chamber is necessary to complete the gas phase combustion reactions.

\section{Materials and methods}

\section{Model assumption}

The combustion chamber considered in the model is shown in Figure 1. On entering the combustion chamber (rotary kiln), the waste is dried, de-volatized, and the residual carbon is burned and its residues reach the end of the kiln where bottom ash is quickly drenched with water, while flue gases pass into the postcombustion chamber and then to the other devices (boiler, to produce superheated steam for energy production, and flue gases treatment units). Figure 1 shows the primary chamber into which the primary air goes in the initial part of the cylinder.

The model's tool was developed, taking into consideration the following items (Marias, 2003):

- a homogenous waste composition and heating values;

- combustion chamber under standard operating conditions;

- constant speed of the waste advancing towards the rotary kiln;

- partition of the combustion chamber into definite volume numbers in the direction of the advancing waste; the parameters are constant along the kiln's height and width.

The mass and thermal balances were taken into account, together with kinetic parameters for the combustion of the specific waste stream. The mass balance considered only the major mass components (C, H, O, N and $\mathrm{S}$ ).

The higher and lower heating values were obtained by real proximate analysis, by applying Dulong's equation (Kathiravale et al, 2003; Parkish et al, 2005) for both the solid (char) and volatile compounds. In the model, the kiln is divided into a defined 


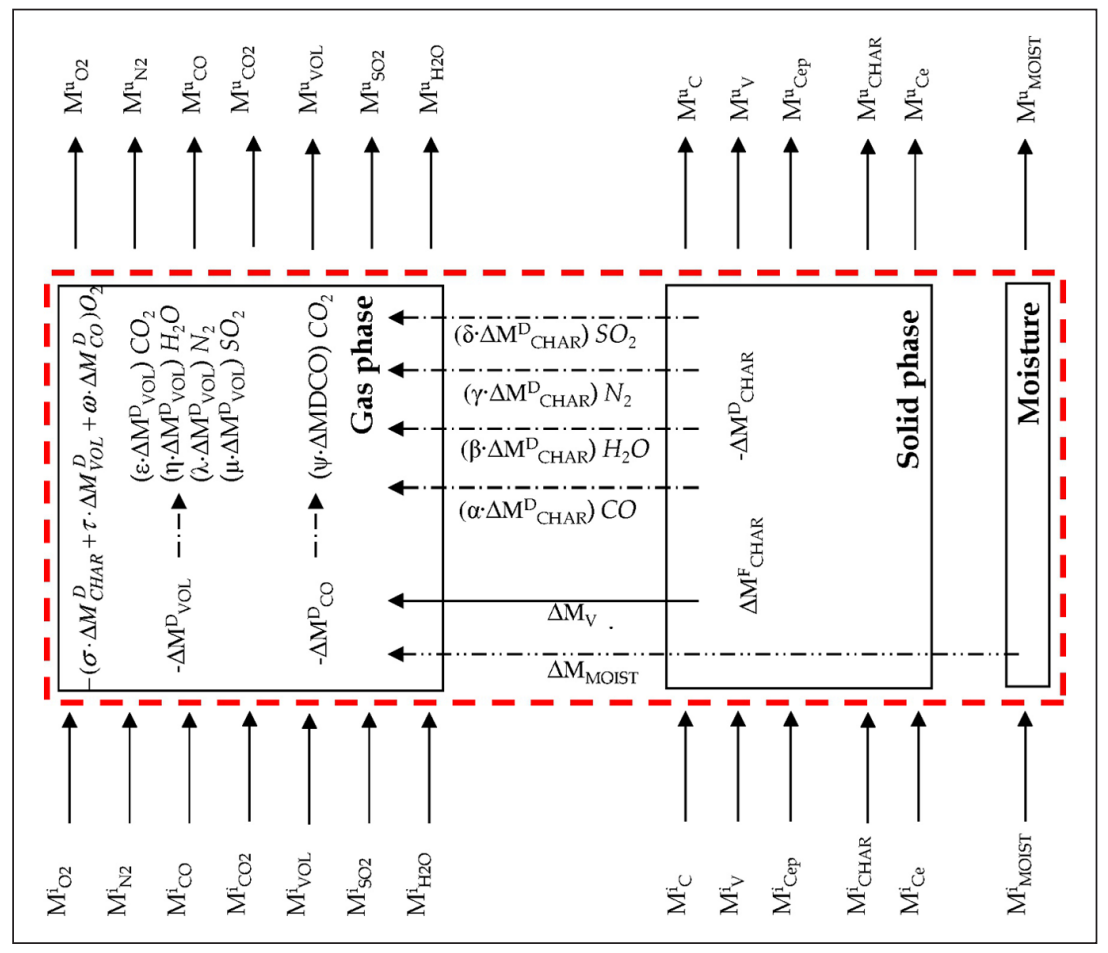

Figure 2. Mass exchanges in every elementary volume.

number of serial volumes (usually 20), which can be set by the user, where all the processes that occur in the kiln are simulated. These processes are: heat and mass exchanges between the different volumes during the combustion reaction, and the different phases inside each volume (solid, gas and moisture) (Shin and Choi, 2000). The model simulates all heat exchanges for radiation between the walls, gas and solids inside each volume, and the heat exchanges between the solid and gas phases of different elementary volumes.

The model calculates the following parameters: temperatures of the solid (waste) and gas phases, the amount of burned and unburned waste, char and volatile compounds (produced and burned). The mass balances during the gas phase produce the following output compounds: carbon monoxide (CO), carbon dioxide $\left(\mathrm{CO}_{2}\right)$, oxygen $\left(\mathrm{O}_{2}\right)$, water $\left(\mathrm{H}_{2} \mathrm{O}\right)$ and sulphur dioxide $\left(\mathrm{SO}_{2}\right)$. The model was applied using the input parameters of the test plant (waste and air rate, geometry of the combustion chamber, waste proximate analysis), and the results obtained from the model were compared with those measured in the plant.

One of the basic hypotheses of the model's tool is that it simulates combustion under stationary conditions, after the kiln has reached operating conditions. For this reason, all of the equations are free of the time factor, which does not influence the final results, and, consequently, the time that the waste remains in the kiln does not influence the temperature or the final composition.

In theory, one parameter that should be important for the model is the speed of the solids as they pass through the kiln (if the velocity is too high, the fuel will not be burned out). However, this parameter is not mentioned at all in the model description because (as mentioned above) the approach indicated seeks to provide a snapshot of the combustion chamber, at moment $\mathrm{x}$, by considering the conditions to be stationary, and therefore, the transportation and speed equations are not considered.

Another model tool assumption is that the size of the ingoing material is not considered. The size is considered implicitly in the choice of kinetic variables for the reactions.

A final hypothesis concerns the ignition of the waste: this is considered to be caused by the exchanges of heat, by radiation, between the first, and then all subsequent volumes, which leads to an increase in the temperature of the waste, which first begins to decompose and then to burn in accordance with the kinetics of the reaction.

\section{Mass balances}

We made a distinction between the moisture and gas phases, by considering the subdivision into three sections of waste, also in accordance with the bibliographical references.

The table of these equations is shown in Figure 2, where all mass exchanges that occurred in each elementary volume are shown.

\section{Combustion process}

Inside the combustion chamber, three different phases (solid, liquid and gas) interact. These three phases follow different processes inside each elementary volume, which are simulated in the model. First of all, the model calculates the highest and lowest heating values of the volatile and char parts separately, using Dulong's equation (Kathiravale et al., 2003; Parkish et al., 2005) (see Appendix 1 for an explanation of all notations in the equations): 


$$
\begin{aligned}
H H V\left(\mathrm{MJ} \mathrm{kg}_{\text {waste }}{ }^{-1}\right)= & 33.95 C \%+144.2(H \%-1 / 80 \%) \\
& +2.36 N \%+9.4 S \%
\end{aligned}
$$

$$
L H V\left(\mathrm{MJ} \mathrm{kg}_{\text {waste }^{-1}}\right)=H H V-2.40(\text { Humidity } \%+9 H \%)
$$

where in the equation $\mathrm{C} \%, \mathrm{H} \%, \mathrm{O}_{2} \%, \mathrm{~N} \%$ and $\mathrm{S} \%$ are the percentage composition for all the components of the waste. The input data for Dulong's equation were obtained from a series of analyses of the physical composition (waste component analysis) of the waste treated in the real plant. It was assumed that the waste composition was homogeneous, when, in a real plant, it is a mixture of various medical wastes. The average composition of the waste is described in the following table. The contribution to the calculation of the average composition of the waste regards only healthcare waste (with the risk of infection) destined for the plant (specific sampling was carried out, and completed with chemical characterization).

The combustion process was then divided into three stages: waste drying, pyrolysis (emanation of volatiles and char), and char and volatile combustion. The three phases were physically in series, but may occur at the same time, depending on the furnace boundary conditions.

Waste drying. After entering the combustion chamber, the waste starts to dry, releasing its water content. There are two possible options for this phase, depending on the temperature value (over or under $373 \mathrm{~K}$ ):

$$
\begin{aligned}
& R_{e v}^{p o t}=S_{a} \cdot h_{s} \cdot\left(C_{w, s}-C_{w, g}\right) \text { when } T<373 K \\
& R_{e v}^{p o t}=\frac{Q_{e v}}{\Delta H_{e v}^{\text {lat }}} \text { when } T>373 K
\end{aligned}
$$

Table 1. Waste composition.

\begin{tabular}{lc}
\hline Material & Composition (\%) \\
\hline Organics & 1.05 \\
Plastics & 39.23 \\
Textiles & 4.45 \\
Papers & 18.07 \\
Liquids & 9.86 \\
Diapers & 12.34 \\
Leathers & 3.82 \\
Fines & 3.38 \\
Metals & 1.32 \\
Glass-inert & 6.16 \\
Various Material & 0.32 \\
\hline
\end{tabular}

As the temperature inside the combustion chamber is always over $373 \mathrm{~K}$, equation (2) is never used. So (3) is the equation that is used, in which:

$$
Q_{e v}=\Delta \dot{M}_{M O I S T} \cdot \Delta H_{e v}^{l a t}
$$

where $\Delta \mathrm{H}^{\text {lat }}$ ev at $373 \mathrm{~K}$ is assumed to be equal to $2257 \mathrm{~kJ} \mathrm{~kg}^{-1}$ (Yang et al., 2002, 2003). In the developed model, it is hypothesised that the drying process of the waste takes place in the first part of the combustion chamber, so the available heat released in these volumes during combustion is transferred mainly to vaporised water; after the first part of the kiln, the heat was available mainly for pyrolysis and combustion during the volatile phase.

Pyrolysis. After the drying process, pyrolysis takes place, and the char and volatile compounds are produced for the combustion phase. Formation rates $\left(\mathrm{R}_{\mathrm{CHAR}}^{\mathrm{F}}, \mathrm{R}_{\mathrm{V}}^{\mathrm{FOL}}\right.$ ) for both phases are modelled using single-order reaction rate emanation models (equations (5) and (6)), where the formation rate is expressed in $\mathrm{kg} \mathrm{s}^{-1}$ using equations taken from the technical literature (Shin and Choi, 2000; Sorum et al., 2001; Yang et al., 2002):

$$
\begin{aligned}
& R_{C H A R}^{F}=\frac{d\left[M_{C H A R}\right]}{d t}=A_{C H A R}^{F} \cdot e^{\left(-\frac{E^{F}{ }_{\text {CHAR }}}{R}\right)} \cdot M_{R I F} \\
& R_{V O L}^{F}=\frac{d\left[M_{V O L}\right]}{d t}=A_{V O L}^{F} \cdot e^{-\frac{E_{\text {VOL }}^{F}}{R}} \cdot M_{R I F}
\end{aligned}
$$

In order to apply these equations correctly, the kinetic factors and activation energy must be correctly estimated. As this particular waste stream has not been investigated in depth in the literature, the first assumption of the model developed was that the average literature values of the kinetic factors and activation energy of similar wastes (some kinds of wood) could be used (Fjellerup et al., 2005; Huai et al., 2008; Yang et al., 2003); these values were then modified by comparing the results of the first simulations with the real values measured on the test plant (Boateng and Barr, 1996). Table 2 shows the kinetic parameters obtained by other authors.

Combustion. The combustion rate $\left(\mathrm{kg} \mathrm{s}^{-1}\right)$ of char compounds is modelled using the following equation (Shin and Choi, 2000; Sorum et al., 2001; Yang et al., 2002):

$$
R_{C H A R}^{D}=\frac{d\left[M_{C H A R}\right]}{d t}=-A_{C H A R}^{C} \cdot S \cdot\left[O_{2}\right]^{a} \cdot \frac{1}{\frac{1}{k_{r} \cdot \zeta}+\frac{1}{k_{m}}}
$$

Table 2. Kinetic parameters for the pyrolysis phase.

\begin{tabular}{lllll}
\hline Parameter & Di Blasi (1998) & Chan et al. (1985) & Thurner and Mann (1981) & Font et al. (1990) \\
\hline Material & Beech wood & Pine wood & Oak wood & Almond shells \\
$E_{\text {CHAR }}\left(\mathrm{kJ} \mathrm{mol}^{-1}\right)$ & 111.7 & 121 & 106.5 & 73.1 \\
$\mathrm{~A}_{\mathrm{CHAR}}\left(\mathrm{s}^{-1}\right)$ & $3.2 \times 10^{9}$ & $1.08 \times 10^{7}$ & $7.377 \times 10^{5}$ & $2.98 \times 10^{3}$ \\
$E_{\text {VOL }}\left(\mathrm{kJ} \mathrm{mol}^{-1}\right)$ & 152.7 & 140 & 88.6 & 139.2 \\
$\mathrm{~A}_{\text {VOL }}\left(\mathrm{s}^{-1}\right)$ & $4.38 \times 10^{9}$ & $1.3 \times 10^{8}$ & 14345 & $1.52 \times 10^{7}$ \\
\hline
\end{tabular}


According to equation (8), the compounds in the flue gases, as a consequence of combustion are: $\mathrm{CO}, \mathrm{H}_{2} \mathrm{O}$, nitrogen $\left(\mathrm{N}_{2}\right)$ and $\mathrm{SO}_{2}$, which are all fully described in the model with their concentrations in each elementary volume.

$$
\begin{gathered}
\mathrm{C}_{a} \mathrm{H}_{b} \mathrm{O}_{c} \mathrm{~N}_{d} \mathrm{~S}_{e}+\mathrm{F} \cdot \mathrm{O}_{2}+3.76 \mathrm{FN}_{2} \rightarrow \mathrm{G} \cdot \mathrm{CO}+\mathrm{L} \cdot \mathrm{H}_{2} \mathrm{O}+ \\
(P+3.76 \mathrm{~A}) \cdot \mathrm{N}_{2}+Q \cdot \mathrm{SO}_{2}
\end{gathered}
$$

where $\mathrm{F}$ is the $\mathrm{O}_{2}$ and $\mathrm{N}_{2}$ flow rate, while $\mathrm{G}, \mathrm{L}, \mathrm{P}$ and $\mathrm{Q}$ are the output of the combustion obtained from the waste $\mathrm{C}_{\mathrm{a}} \mathrm{H}_{\mathrm{b}} \mathrm{O}_{\mathrm{c}} \mathrm{N}_{\mathrm{d}} \mathrm{S}_{\mathrm{e}}$ $\left(\mathrm{kg} \mathrm{s}^{-1}\right)$. Equation (8) (Huai et al., 2008) is generic, where F, G, L, $\mathrm{Q}$, etc., are the stoichiometric coefficients of the various substances, which can be obtained once the approximate chemical formula of the waste is known.

The model describes incomplete waste combustion, with the formation of $\mathrm{CO}$ (equation (8)); it then considers that the $\mathrm{CO}$ and volatile compounds burn in a homogenous mix in the gaseous phase. Equations (9) and (10) (Huai et al., 2008) describe the CO and volatile compounds combustion rates $\left(\mathrm{kmol} \mathrm{m}^{-3} \mathrm{~s}^{-1}\right)$.

$$
\begin{gathered}
R_{V O L}^{D}=\frac{d[V O L]}{d t}=-A_{V O L}^{C} \cdot e^{-\frac{E_{\text {VOL }}^{c}}{R T_{G}}} \cdot\left[O_{2}\right]^{a} \cdot[V O L]^{b} T_{G} P^{0.3} \\
R_{C O}^{D}=\frac{d[C O]}{d t}=-A_{C O}^{C} \cdot e^{-\frac{E_{C o}^{c}}{R T_{G}}} \cdot\left[\mathrm{O}_{2}\right]^{a} \cdot[C O]^{b} \cdot\left[\mathrm{H}_{2} \mathrm{O}\right]^{c}
\end{gathered}
$$

where $\mathrm{A}^{\mathrm{c}}$ is the kinetic constant of the specific compounds $\left(1 \mathrm{~s}^{-1}\right)$ (equal to $1.3 \times 10^{11} \mathrm{CO}$ and 59.8 for volatiles), $\mathrm{E}^{\mathrm{C}} / \mathrm{R}$ is the reaction activation energy $(15,105 \mathrm{~K}$ for $\mathrm{CO}$, and $12,200 \mathrm{~K}$ for volatiles; Fjellerup et al., 2005; Sorum et al., 2001; Yang et al., 2003), $\mathrm{T}_{\mathrm{g}}$ is the gas temperature $(\mathrm{K}), \mathrm{P}$ is the pressure inside the combustion chamber $(\mathrm{Pa})$, and $\mathrm{O}_{2}$, VOL, $\mathrm{CO}, \mathrm{H}_{2} \mathrm{O}$ are the gas concentrations $\left(\mathrm{kmol} \mathrm{m}^{-3}\right)$.

Volatile combustion is modelled using equation (11), which implies that the following compounds are formed: $\mathrm{CO}_{2}, \mathrm{H}_{2} \mathrm{O}, \mathrm{N}_{2}$ and $\mathrm{SO}_{2} ; \mathrm{CO}$ combustion is governed by equation (12).

$$
\begin{gathered}
\mathrm{C}_{x} \mathrm{H}_{y} \mathrm{O}_{z} \mathrm{~N}_{w} \mathrm{~S}_{u}+\mathrm{A} \cdot \mathrm{O}_{2}+3.76 \mathrm{~A} \cdot \mathrm{N}_{2} \rightarrow \mathrm{B} \cdot \mathrm{CO}_{2}+\mathrm{C} \cdot \mathrm{H}_{2} \mathrm{O}+ \\
(\mathrm{D}+3.76 \mathrm{~A}) \cdot \mathrm{N}_{2}+\mathrm{E} \cdot \mathrm{SO}_{2}
\end{gathered}
$$

where $\mathrm{A}$ is the $\mathrm{O}_{2}$ and $\mathrm{N}_{2}$ flow rate, while $\mathrm{B}, \mathrm{C}, \mathrm{D}$ and $\mathrm{E}$ are the output of the combustion obtained from the waste $\mathrm{C}_{x} \mathrm{H}_{\mathrm{y}} \mathrm{O}_{\mathrm{z}} \mathrm{N}_{\mathrm{w}} \mathrm{S}_{\mathrm{u}}$ $\left(\mathrm{kg} \mathrm{s}^{-1}\right)$.

$$
\mathrm{CO}+\frac{1}{2} \mathrm{O}_{2} \rightarrow \mathrm{CO}_{2}
$$

The flue gas concentration and composition is obtained for each elementary volume, coupled with the char combustion products. Minor pollutants, such as hydrochloric acid, mono-nitrogen oxides $\left(\mathrm{NO}_{\mathrm{x}}\right)$, hydrogen fluoride and dust, are not taken into account (very low concentrations and insignificant combustion).

\section{Energy balances}

Thermal balances include the heat produced by combustion, all of the possible exchanges between the different elementary volumes and the different phases of the same volume, and thermal dispersion towards the outside of the combustion chamber. All of these exchanges are described in the following sections, with particular attention paid to the final thermal balances of the solid and gaseous phases.

Heat conduction. Heat conduction exchanges take place between the solid or gas phases, and the kiln side wall. The dispersions towards the exterior of the kiln are calculated using the following expressions (equation (13) indicates the exchanges between the gas and the kiln wall, while equation (14) indicates the exchanges between the solid and the kiln wall):

$$
\begin{gathered}
\dot{Q}_{P, G}=\frac{T_{G}-T_{e x t}}{\frac{\ln \left(r_{2} / r_{1}\right)}{2 \pi \cdot k_{r e}\left(T_{G}\right) \cdot \Delta x}+\frac{\ln \left(r_{3} / r_{2}\right)}{2 \pi \cdot k_{i s}\left(T_{G}\right) \cdot \Delta x}+\frac{1}{2 \pi r_{3} \Delta x h_{e s t}}} \cdot C_{G \%} \\
\dot{Q}_{P, S}=\frac{T_{S}-T_{e x t}}{\frac{\ln \left(r_{2} / r_{1}\right)}{2 \pi \cdot k_{r e}\left(T_{S}\right) \cdot \Delta x}+\frac{\ln \left(r_{3} / r_{2}\right)}{2 \pi \cdot k_{i s}\left(T_{S}\right) \cdot \Delta x}+\frac{1}{2 \pi r_{3} \Delta x h_{e s t}}} \cdot C_{S \%}
\end{gathered}
$$

where $\mathrm{T}_{\mathrm{G}}, \mathrm{T}_{\mathrm{S}}$ and $\mathrm{T}_{\mathrm{ext}}$ are the gas, solid and external temperatures, respectively $(\mathrm{K}), \mathrm{r}_{1}, \mathrm{r}_{2}$ and $\mathrm{r}_{3}$ are the radii of the kiln, insulator and refractory layers (m), respectively, $\mathrm{k}_{\mathrm{is}}$ and $\mathrm{k}_{\mathrm{re}}$ are the thermal conductivities of the insulator and refractory materials $\left(\mathrm{Wm}^{-1} \mathrm{~K}^{-1}\right), \Delta \mathrm{x}$ is the length of the elementary volume $(\mathrm{m}), \mathrm{h}_{\mathrm{est}}$ is the external wall conductance $\left(18 \mathrm{~W} \mathrm{~m}^{-2} \mathrm{~K}^{-1}\right)$, and $\mathrm{C}_{\mathrm{G} \%}$ and $\mathrm{C}_{\mathrm{S} \%}$ are the contact surfaces, in the external wall-gas and external wall-solid phases (m).

These expressions are defined in accordance with the geometry of the combustion chamber; the external wall consists of a layer of insulating material and then the internal refractory material.

Heat convection. Heat convection exchanges inside the same elementary volume are defined by the following expression (15):

$$
\begin{gathered}
\dot{Q}_{C O N V}=-h \cdot S_{C O N V} \cdot\left(T_{G}-T_{S}\right) \\
h=\frac{N u \cdot k_{f}}{L}
\end{gathered}
$$

where $T_{G}$ and $T_{S}$ are, respectively, the temperatures of the gas and solid phases in the specific volume $(\mathrm{K}), \mathrm{S}_{\mathrm{CONV}}$ is the separation surface between the solid and gas phases $\left(\mathrm{m}^{2}\right)$ and $\mathrm{h}$ is the coefficient for the convection exchange given by expression $16\left(\mathrm{~N}_{\mathrm{u}}\right.$ is the Nusselt factor, $\mathrm{k}_{\mathrm{f}}$ is the fluid conductivity, and $\mathrm{L}$ the characteristic length).

The surface $\mathrm{S}_{\mathrm{CONV}}$ is owing to the length of the elementary volume and the contact surface between the gas and solid phase. The contact surface is an irregular surface that, in the model, has been simplified according to the following equation depending also by the filling coefficient of the waste in the kiln $(\varphi)$ and the internal radius of the kiln $\left(\mathrm{r}_{\text {kiln }}\right)$. 


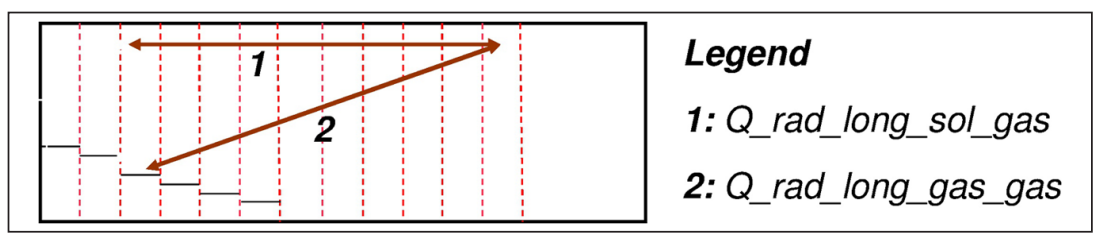

Figure 3. Radiation exchange between the volumes of the combustion chamber.

$$
\begin{gathered}
S_{C O N V}=2 \cdot r_{k i \ln } \cdot \operatorname{sen}\left(\frac{C_{S}}{2 \cdot r_{1}}\right) \cdot \Delta x \\
C_{S}=r_{k i \ln } \cdot\left(\begin{array}{l}
5.3291 \phi^{6}+76.64 \cdot \phi^{5}-213.41 \cdot \phi^{4}+ \\
204.61 \cdot \phi^{3} .87 .499 \cdot \phi^{2}+19.777 \cdot \phi+0.3969
\end{array}\right)
\end{gathered}
$$

Heat radiation model. Heat radiation exchanges are more complex; for this reason, two different contributions to radiation exchanges inside the combustion chamber are considered. The first part is due to the heat exchange of different phases of the same volume (wall, solid and gas phase).

Exchanges between the walls and gas phase are non-existent because it is hypothesised that they are at the same temperature. Radiation exchanges between the walls and solid phase are calculated using equation (19) (valid for computational domain without gas radiation) (Boateng and Barr, 1996):

$$
\begin{aligned}
Q_{t_{-} s p} & =\sigma_{0} A_{w a l} F_{w a l, s}\left(T_{w a l}^{4}-T_{s}^{4}\right) \\
& =\sigma_{0} A_{s} F_{s, w a l}\left(T_{s}^{4}-T_{w a l}^{4}\right)
\end{aligned}
$$

where $\sigma_{0}$ is the Stefan-Boltzmann constant $\left(5.67 * 10^{-8} \mathrm{Wm}^{-2} \mathrm{~K}^{-4}\right)$, $\mathrm{T}_{\mathrm{wal}}$ and $\mathrm{T}_{\mathrm{s}}$ are the temperatures of the walls and the solid phase $(\mathrm{K}), \mathrm{F}$ is the view factor between the two different forms and $A_{w a l}$ and $A_{s}$ are the surfaces of the external walls and the solid phase $\left(\mathrm{m}^{2}\right)$.

The radiated heat between the solid and gas phases is calculated according to Leckner (1972):

$$
Q_{\text {rad_sol_gas }}=\eta_{s o l} \sigma\left\{\begin{array}{l}
{\left[1-\alpha\left(L_{g s}\right)\right] T_{s}^{4}-} \\
\varepsilon\left(L_{g s}\right) T_{g}^{4}
\end{array}\right\}
$$

where $\eta$ is the emissivity, $\alpha$ is the solid phase absorbance, $\varepsilon$ is the gas phase emissivity, $\sigma$ is the Stefan-Boltzmann constant $\left(5.67^{*} 10^{-8}\right.$ $\left.\mathrm{Wm}^{-2} \mathrm{~K}^{-4}\right), \mathrm{T}_{\mathrm{g}}$ and $\mathrm{T}_{\mathrm{s}}$ are the solid and gas phase temperatures $(\mathrm{K})$, and $\mathrm{L}$ is the average distance between the two phases (m).

Other contributions considered are also due to the exchanges between different elementary volumes, involving the solid phase of each volume and the gas phase of all other volumes (Figure 3).

The heat radiated between the different elementary gas volumes is modelled using the following equation (Leckner, 1972):

$$
\begin{gathered}
\text { Qrad_long_gas_gas }=\varepsilon_{i} \cdot \varepsilon_{j}\left[\frac{\left(S g_{i}+S g_{j}\right)}{2}\right] . \\
\left(K_{v}+K_{R A D}\right) \cdot\left(T_{j}-T_{i}\right) / L_{g g}
\end{gathered}
$$

where $\varepsilon_{\mathrm{i}}$ and $\varepsilon_{\mathrm{j}}$ are the emissivity of volumes $\mathrm{i}$ and $\mathrm{j}$, respectively, calculated according with the Leckner formulas considering the $\mathrm{CO}_{2}$ and $\mathrm{H}_{2} \mathrm{O}$ emissivity, which are the most important factors that influence the gaseous emissivity inside the kiln (Leckner, 1972), $\mathrm{Sg}_{\mathrm{i}}$ and $\mathrm{Sg}_{\mathrm{j}}$ are the surfaces that contribute effectively to the radiation exchanges $\left(\mathrm{m}^{2}\right), \mathrm{T}_{\mathrm{j}}$ and $\mathrm{T}_{\mathrm{i}}$ are the temperatures of the different volumes $(\mathrm{K}), \mathrm{L}$ is the distance between the volume concerned $(\mathrm{m}), \mathrm{K}_{\mathrm{v}}$ is the internal conductivity $\left(\mathrm{Wm}^{-1} \mathrm{~K}^{-1}\right)$ and depends on the gas composition and temperature, $\mathrm{K}_{\mathrm{RAD}}$ is the radiant conductivity $\left(\mathrm{Wm}^{-1} \mathrm{~K}^{-1}\right)$, which, in accordance with equation (22), depends on the temperature of the different volumes $\left(T_{j}\right.$ and $\left.T_{i}\right)$, the Stefan-Boltzmann constant $(\sigma)$, the distance between the volumes (L) and the emissivity $(\varepsilon)$ :

$$
K_{R}=\frac{16 \sigma}{3\left(-\frac{\ln (1-\varepsilon)}{L}\right)}\left(T_{i}^{3}-T_{j}^{3}\right)
$$

The radiation heat exchanged between the solid phase and all the other gas phase volumes is summarised in equation (23):

$$
\begin{array}{r}
Q_{\text {rad_long_gas_sol }}=S s .\left(K_{v}+K_{R}\right) . \\
\left(T g_{j}-T s_{i}\right) / L_{g-s}
\end{array}
$$

where Ss is the gas surface that contributes effectively to the radiation exchanges $\left(\mathrm{m}^{2}\right), \mathrm{Tg}_{\mathrm{j}}$ and $\mathrm{T}_{\mathrm{Si}}$ are the temperatures of the different volumes $(\mathrm{K}), \mathrm{L}_{\mathrm{g}_{\mathrm{S}} \mathrm{S}}$ is the distance between the volumes concerned $(\mathrm{m}), \mathrm{K}_{\mathrm{v}}$ is the internal conductivity $\left(\mathrm{Wm}^{-1} \mathrm{~K}^{-1}\right)$ and $\mathrm{K}_{\mathrm{R}}$ is the radiant conductivity $\left(\mathrm{W} \mathrm{m}^{-1} \mathrm{~K}^{-}\right)$.

Thermal balances. All of the terms indicated earlier contribute to the final thermal balances of the solid and gas phases (equations (24) and (25)). These equations must be solved for each elementary volume; their solution gives the temperatures of each volume for the gas and solid phases (Figure 4), where all the terms indicated correspond with the heat exchanges of each finite volume for the gas and solid phase, and $\dot{Q}_{R A D}$ is the sum of all the heat exchanges for radiation.

The model developed calculates the temperatures of each phase in an iterative way until the calculated temperatures between two consecutive iterations are less than the tolerance limit of the model for the convergence of the model, which is set by the user (typically 1 or $3 \mathrm{~K}$ ), for each volume.

The thermal balance equation is obtained from the convergence of the model results. The starting simulation made by the model requires a first run, where every radiation exchange between the different volumes is zero. This is necessary because the model uses the temperature calculated in the i- 1 iteration to estimate the radiation heat exchanged between the different 


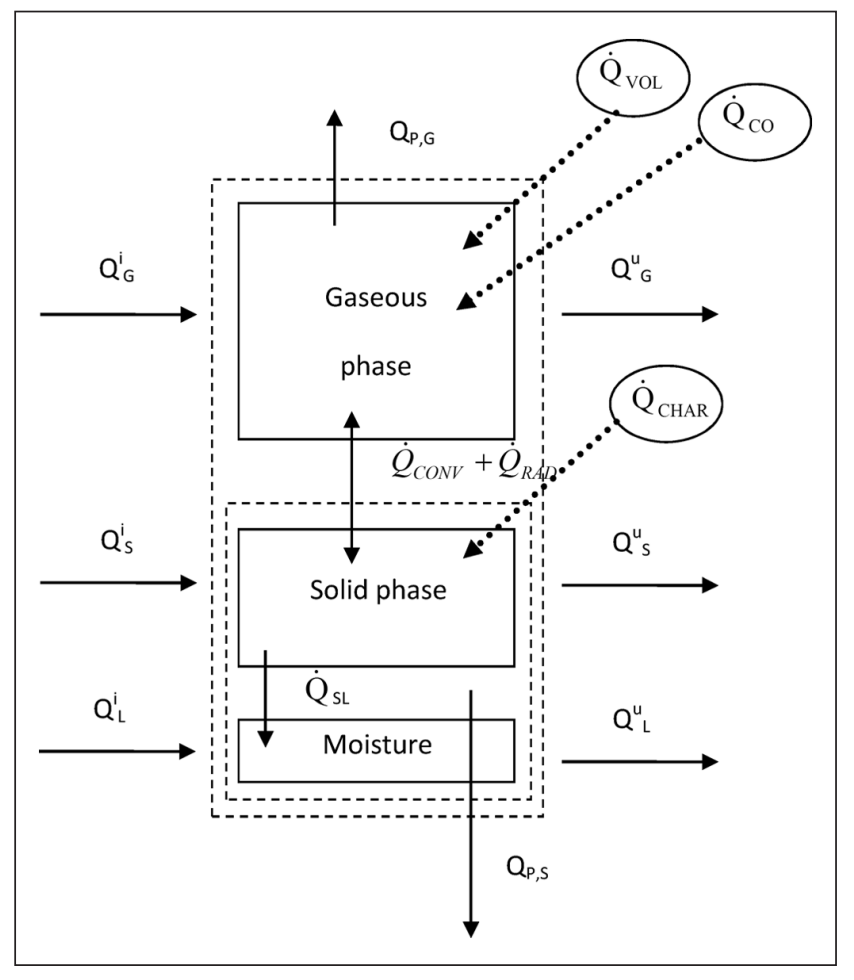

Figure 4. Description of the finite volume exchange processes.

volumes. Thus, after the first iteration, the model calculates all of the heat contributions in the next iteration and runs until the final convergence is obtained:

$$
\begin{aligned}
& \left(\sum c_{p r}^{u} \cdot M_{x}^{u}\right) \cdot\left(T_{G}^{u}-T_{R F}\right)-\left(\sum c_{p x}^{i} \cdot M_{x}^{i}\right) \cdot\left(T_{\sigma}^{i}-T_{R F}\right)= \\
& \Delta M_{v o L}^{D} \cdot \overline{P C I}_{v o L}+\Delta M_{c o}^{D} \cdot \overline{P C I}_{c o}+c_{p r o t} \cdot \Delta M_{v o L}^{F} \cdot\left(T_{\sigma}^{i}-T_{R r}\right)+
\end{aligned}
$$

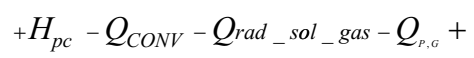

$$
\begin{aligned}
& +{ }^{+} \text {rad_long_gas_gas }-Q_{r a d} \text { long_gas_sol }
\end{aligned}
$$

where $\mathrm{T}_{\mathrm{G}}^{\mathrm{i}}$ and $\mathrm{T}_{\mathrm{G}}^{\mathrm{u}}$ are the initial and final gas phase temperatures, $\mathrm{c}_{\mathrm{px}}^{\mathrm{i}}$ and $\mathrm{c}_{\mathrm{px}}^{\mathrm{u}}$ are the initial and final specific heats of the gas phase, $\mathrm{M}_{\mathrm{x}}^{\mathrm{i}}$ and $\mathrm{M}_{\mathrm{x}}^{\mathrm{u}}$ are the initial and final quantities of gas, $\Delta \mathrm{M}_{\text {vOL }}^{\mathrm{D}}$ and $\Delta \mathrm{M}_{\mathrm{CO}}^{\mathrm{D}}$ are the quantities of volatiles and $\mathrm{CO}$ burned in the elementary volume, $\mathrm{PCI}_{\mathrm{VOL}}$ and $\mathrm{PCI}_{\mathrm{CO}}$ are the lower heat values for the volatiles and $\mathrm{CO}$, respectively, $\Delta \mathrm{M}^{\mathrm{F}} \mathrm{vOL}$ is the quantity of volatiles formed in the elementary volume, and $\mathrm{c}_{\mathrm{p}}{ }^{\mathrm{vol}}$ is the specific heat of the volatiles; the remaining terms indicate the abovementioned heat exchanges between the different volumes and phases:

$$
\begin{aligned}
& \left(c_{p C v e} \cdot M_{C v e}^{i}+c_{p C h a r} \cdot M_{c h a r}^{i}+c_{p C e} \cdot M_{C e}^{i}\right) \cdot\left(T_{S}^{i}-T_{R I F}\right)+\left(c_{p C r e} \cdot M_{C v e}^{u}\right. \\
& \left.+c_{p C h a r} \cdot M_{c h a r}^{u}+c_{p C e} \cdot M_{C e}^{u}\right) \cdot\left(T_{S}^{u}-T_{R I F}\right)=\Delta M_{\text {moist }} \cdot \Delta H_{E V}^{\text {lat }}+ \\
& +\mathcal{c}_{\text {pChar }} \cdot \Delta M_{\text {CHAR }}^{F} \cdot\left(T_{S}^{i}-T_{R I F}\right)+Q_{C O N V}+Q_{r a d}{ }_{\text {_long_gas_sol - }} \\
& -\Delta M_{\text {char }}^{D} . \overline{P C I} I_{\text {char }}+Q_{\text {rad_gas_sol }}+Q_{P, S}+Q_{\text {rad_sol_par }}
\end{aligned}
$$

where $\mathrm{T}_{\mathrm{S}}^{\mathrm{i}}$ and $\mathrm{T}_{\mathrm{S}}^{\mathrm{u}}$ are the initial and final solid phase temperatures, $\mathrm{c}_{\mathrm{pCve}}, \mathrm{c}_{\mathrm{pChar}}$ and $\mathrm{c}_{\mathrm{pCe}}$ are the specific heat, respectively, of

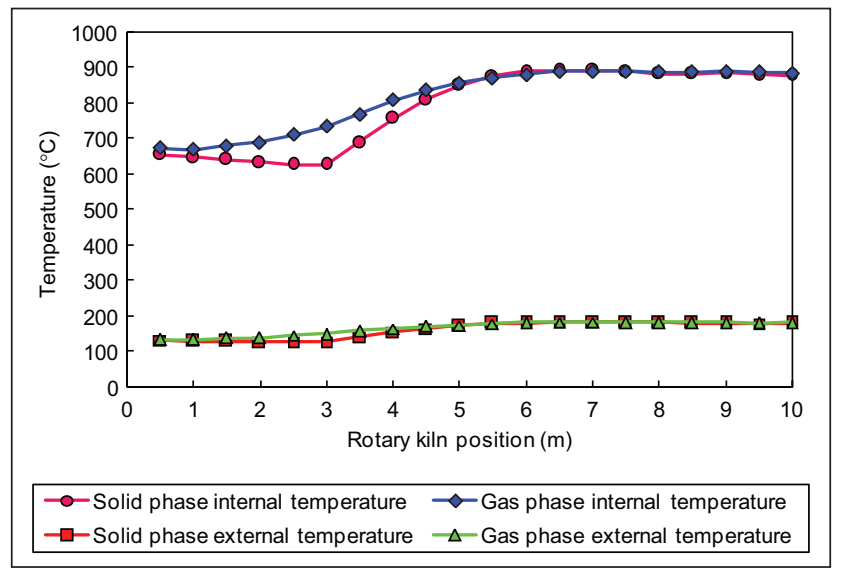

Figure 5. Internal and external temperatures of the solid and gaseous phase.

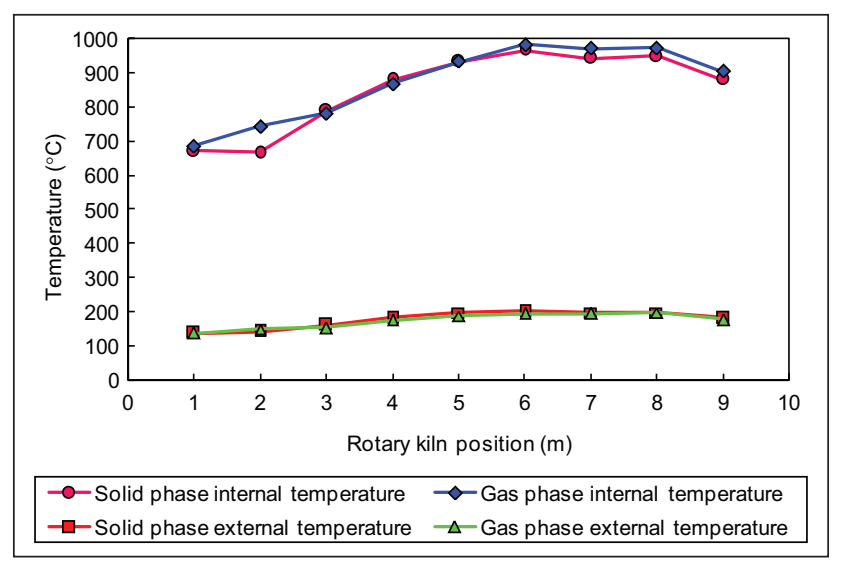

Figure 6. External temperatures measured in the test plant and the corresponding calculated internal temperatures.

the waste, char and ash, $\mathrm{M}_{\text {cve }}, \mathrm{M}_{\text {char }}$ and $\mathrm{M}_{\mathrm{Ce}}$ are quantities, respectively, of waste, char and ash, $\Delta \mathrm{M}_{\text {moist }}$ is the evaporated moisture, $\Delta \mathrm{M}^{\mathrm{F}}$ char is the quantity of char formed in the elementary volume, $\Delta \mathrm{M}^{\mathrm{D}}{ }_{\mathrm{CHAR}}$ is the quantity of char burned in the elementary volume and $\mathrm{PCI}_{\mathrm{CHAR}}$ is the char lower heating value; the remaining terms indicate the abovementioned heat exchanges between the different volumes and phases.

\section{Results}

The results of the simulation were tested and improved by comparing them with real measurements made in a healthcare waste incinerator; the model results are the calculation of all of the most important parameters that regulate waste combustion. Table 3 presents the main characteristics of the rotary kiln considered.

Figure 5 shows the main response of the model's tool in which (as pointed out above) the internal temperatures of the solid and gaseous phases must converge in order to obtain the correct response to the solution. Figure 6 shows the temperatures measured on the outside and those calculated for the inside. 
The temperature obtained from the model's tool were compared with those calculated by measuring the external wall temperatures of the kiln. In fact, from the external wall temperatures measured and the kiln material system (iron and refractory), the internal temperature can be calculated. This procedure was carried out as it was impossible to measure the temperatures inside the kiln because of the manifold limits (kiln rotation, presence of a flame, high temperatures). The temperatures outside the kiln were determined by means of a series of measurements in the real plant using an infrared temperature probe. The corresponding internal temperature was calculated using the part of the model that simulates heat dispersion towards the outside of the kiln (insulating and refractory material); the level of precision of these calculations is sufficient to allow evaluating the internal temperature of the kiln in this way. These two data series validated the model, indicating very few differences between the calculated and the measured internal kiln temperatures.

Table 3. Rotary kiln characteristics.

\begin{tabular}{|c|c|}
\hline Parameter & Value \\
\hline Kiln internal diameter (m) & 2.65 \\
\hline Kiln length (m) & 10 \\
\hline Refractory material thickness $(\mathrm{cm})$ & 22 \\
\hline \multirow{3}{*}{$\begin{array}{l}\text { Refractory material thermal } \\
\text { properties }\left(\mathrm{W} \mathrm{m}^{-1} \mathrm{~K}^{-1}\right)\end{array}$} & $0.53\left(400^{\circ} \mathrm{C}\right)$ \\
\hline & $0.72\left(800^{\circ} \mathrm{C}\right)$ \\
\hline & $0.84\left(1000^{\circ} \mathrm{C}\right)$ \\
\hline Insulator material thickness (cm) & 9.8 \\
\hline $\begin{array}{l}\text { Insulator material thermal } \\
\text { properties }\left(\mathrm{W} \mathrm{m}^{-1} \mathrm{~K}^{-1}\right)\end{array}$ & $2.9-0.0006 * T(K)$ \\
\hline Air temperature $\left({ }^{\circ} \mathrm{C}\right)$ & 15 \\
\hline $\begin{array}{l}\text { Convection coefficient with the } \\
\text { external wall }\left(\mathrm{W} \mathrm{m}^{-2} \mathrm{~K}^{-1}\right)\end{array}$ & 18 \\
\hline $\begin{array}{l}\text { Waste temperature in the first } \\
\text { volume }\left({ }^{\circ} \mathrm{C}\right)\end{array}$ & 660 \\
\hline $\begin{array}{l}\text { Air temperature in the first } \\
\text { volume }\left({ }^{\circ} \mathrm{C}\right)\end{array}$ & 670 \\
\hline Waste flow rate $\left(\mathrm{kg} \mathrm{h}^{-1}\right)$ & 1690 \\
\hline Excess air ratio & 1.8 \\
\hline Waste residence time (min) & 120 \\
\hline
\end{tabular}

The other results of the model give the flow rates of the solid phase in every volume (Figure 7a); this graph shows the quantities of water (as moisture of the waste), waste (solid and liquid), char and bottom ash in each volume. Evaporation of the water (moisture) continues for 2-2.5 $\mathrm{m}$ while the combustion processes have already started (decrease in solid and liquid waste and slow increasing in bottom ash after the first volumes).

With respect to the capacity values indicated, the trend (black), on the basis of the length of the kiln, expresses the quality of waste. The red line shows the amount of water $\mathrm{m} / \mathrm{m}$ that is evaporated after the first $3 \mathrm{~m}$, because all of the water is evaporated. The green line is the char that begins to form when the moisture has been almost entirely consumed, and has fairly significant values in the $2-5 \mathrm{~m}$ section, and then disappears. The purple line shows the quantity of bottom ash that is formed during the combustion.

Figure 7(b) shows the availability of char and volatiles in every volume; these tend to decrease to a very negligible values after $6.5-7 \mathrm{~m}$, indicating how the combustion phase is nearly finished in the last part of the kiln.

The gas phase flow rates show a significant decrease in the oxygen concentration (Figure 8) in the first part of the kiln where, according to the previous figures, most of the waste combustion takes place. The increase in $\mathrm{CO}_{2}$ and $\mathrm{H}_{2} \mathrm{O}$ in the same volumes can be seen with the oxygen decrease, showing how the middle volumes of the kiln are crucial for combustion. The increase in $\mathrm{CO}$ and $\mathrm{SO}_{2}$, confirming that there is sulphur in the waste, can also be seen in the same volume, although with lower values. The increase in CO was only momentary because, as soon as it forms, it becomes part of the gas combustion phase with the volatile phase of the waste, which reduces its concentration to negligible values.

\section{Discussion}

After the previous steps, the model was used to perform a sensitivity analysis of kiln behaviour using various operating and design parameters. The real geometry and operational conditions of the test plant were used to develop the model; every variation from the average value in these boundary conditions leads to different

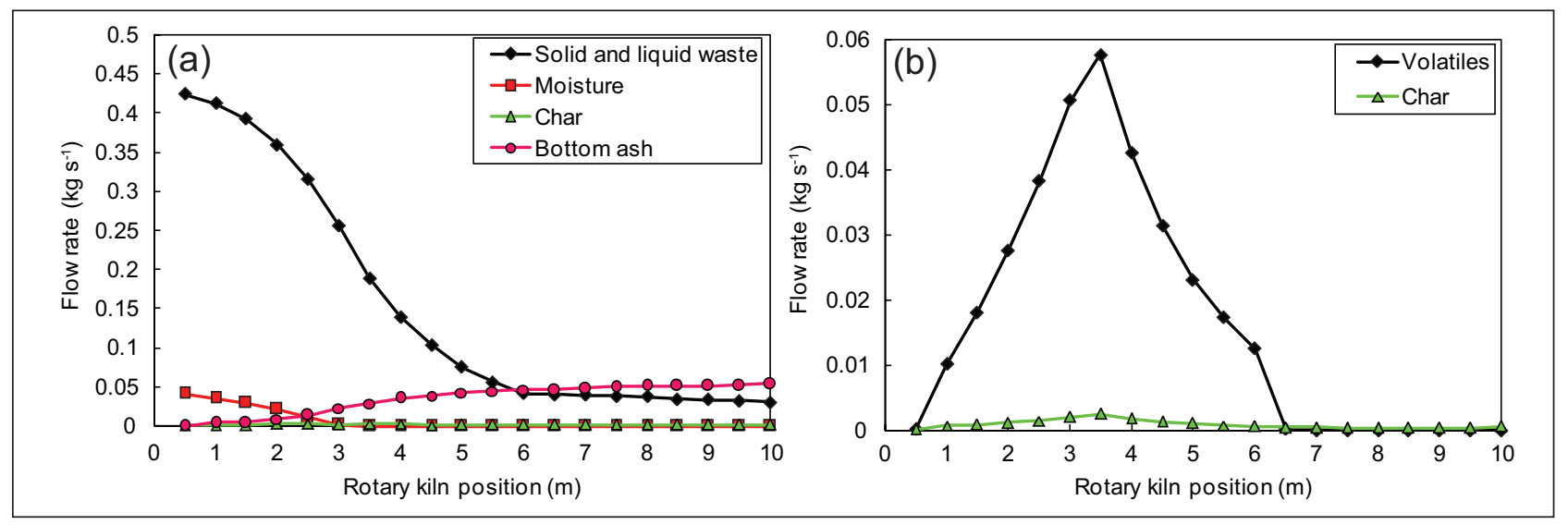

Figure 7. (a) Solid phase flow rates. (b) Char and volatile flow rates. 
plant working conditions (Huai et al., 2008). These variations are simulated by the model to obtain as much information as possible about possible plant optimisation and improvements; three different working conditions can be obtained by varying the following parameters (Table 4):

- waste flow rates;

- excess of air ratio;

- refractory and insulator features.

\section{Influence of input waste flow rates}

Increasing the input waste inside the kiln leads to a higher quantity of volatiles and char compounds available for the combustion processes; the consequence is a higher temperature of the rotary kiln. The model calculations consider three different flow rates (the average values of the test plant were 1690, 2100 and $1300 \mathrm{~kg}$ $\mathrm{hr}^{-1}$ respectively) to study the behaviours of the system.

Obviously, higher values of temperature, moisture, bottom ash, char and volatiles are recorded when larger quantities of waste are fed.

\section{Influence of the excess air ratio}

The excess air ratio is a crucial factor that ensures complete waste combustion and, at the same time, maximises energy recovery. An insufficient excess air ratio leads to incomplete waste combustion,

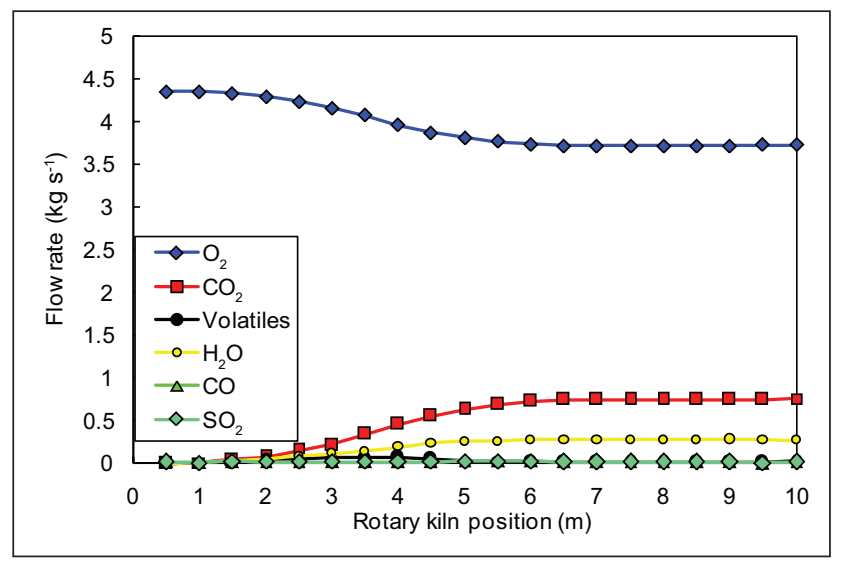

Figure 8. Gas phase flow rates. $\mathrm{O}_{2}$ : oxygen; $\mathrm{CO}_{2}$ : carbon dioxide; $\mathrm{H}_{2} \mathrm{O}$ : water; $\mathrm{CO}$ : carbon monoxide; $\mathrm{SO}_{2}$ : sulphur dioxide. with the formation of very high quantities of $\mathrm{CO}$ and a huge quantity of incompletely burned waste in the bottom ash. Very high air excess ratio values tend to complete combustion processes, increasing kiln turbulence but, at the same time, they decrease the temperature of the rotary kiln as consequence of the cooling effect owing to the temperature of the external air, which absorbs part of the heat inside the kiln. In this way, the performance of the heat recovery supply is reduced. Figure 9 shows the results of the model at different excess air ratios of 1.35; a similar graph can be drawn for different excess air ratios. In this case study, the excess air ratio of 2.25 was also simulated. These values are, respectively, lower and higher than 1.8 (the average value of the test plant), and were adopted to evaluate the sensitivity of the response. Unlike the variation in waste input, the change in the excess air ratio caused only differences in the temperatures and composition of the flue gas. The temperature in the last part of the kiln reached $920-930^{\circ} \mathrm{C}$, with a lower excess air ratio (Figure 10); these temperatures were not reached with a higher excess air ratio (excess air ratio 2.25), where the maximum temperatures were about 860 $870^{\circ} \mathrm{C}$, owing to the cooling effect, resulting in lower energy recovery from the waste.

The flue gas composition was influenced by the excess air ratio because the oxygen concentration was much higher when the excess air ratio value was higher. In fact, the oxygen concentration trend was always higher than $4 \mathrm{~kg} \mathrm{~s}^{-1}$, and the $\mathrm{CO}_{2}$ trend (stable and final condition) occurred at about $6.5 \mathrm{~m}$ of the kiln length (up to $7 \mathrm{~m}$ of the kiln length).

\section{Influence of the features of refractory and insulator materials}

The features of the refractory and insulator materials are very important in protecting the integrity of the combustion chamber and, at the same time, in maximising the energy recovered from the waste. Any change in the thermal properties of these materials leads to different behaviour inside the combustion chamber. The use of materials with low insulation properties results in the dispersion of heat and a lower temperature inside the chamber. The refractory materials in a rotary kiln combustion chamber are important because they determine the quantity of heat available in the boiler (refractory properties relate also to the thermal properties). Moreover, refractory consumption or failure may produce abrasion/corrosion of piping.

Table 4. Parameter variation for following model elaboration.

\begin{tabular}{llll}
\hline & Actual properties & Elaboration 1 & Elaboration 2 \\
\hline Waste flow rate $\left(\mathrm{kg} \mathrm{h}^{-1}\right)$ & 1690 & 2100 & 1300 \\
Excess air ratio & 1.8 & 1.35 & 2.25 \\
Refractory thickness $(\mathrm{cm})$ & 22 & 12 & 16,5 \\
Refractory conductivity $\left(\mathrm{W} \mathrm{m} \mathrm{m}^{-1} \mathrm{~K}^{-1}\right)$ & $2.9-0.0006 * \mathrm{~T}$ & $5-0.0009 * \mathrm{~T}$ & $3.63-0.00075^{*} \mathrm{~T}$ \\
Insulating thickness $(\mathrm{cm})$ & 9.8 & 6 & 7.5 \\
Insulating conductivity $400^{\circ} \mathrm{C}\left(\mathrm{W} \mathrm{m}^{-1} \mathrm{~K}^{-1}\right)$ & 0.53 & 0.8 & 0.663 \\
Insulating conductivity $800^{\circ} \mathrm{C}\left(\mathrm{W} \mathrm{m}^{-1} \mathrm{~K}^{-1}\right)$ & 0.72 & 1.1 & 0.90 \\
Insulating conductivity $1000^{\circ} \mathrm{C}\left(\mathrm{W} \mathrm{m}^{-1} \mathrm{~K}^{-1}\right)$ & 0.84 & 1.4 & 1.05 \\
\hline
\end{tabular}



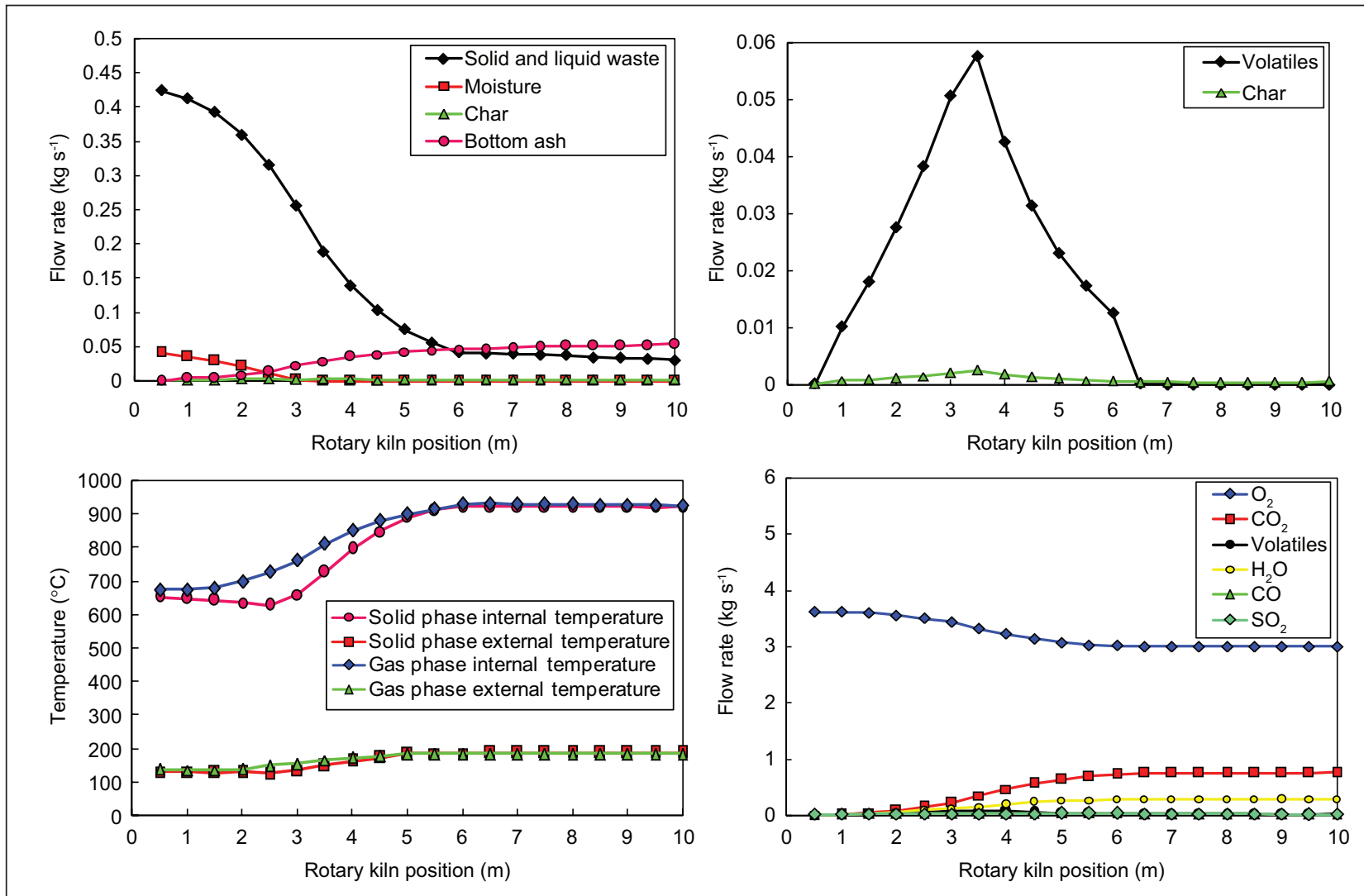

Figure 9. Excess air ratio of 1.35. $\mathrm{O}_{2}$ : oxygen; $\mathrm{CO}_{2}$ : carbon dioxide; $\mathrm{H}_{2} \mathrm{O}$ : water; $\mathrm{CO}$ : carbon monoxide; $\mathrm{SO}_{2}$ : sulphur dioxide.

Figure 10 shows the case of processing 1 of the model for the thermal properties and thicknesses of different refractory and insulation materials; the features and thicknesses of the material are shown in Table 3. The processing of the model with different thicknesses and properties of the material led to notable changes in the internal and external temperatures. Materials that have a higher conductivity and lower thickness were considered in processing 2 (processing 1 was the actual configuration, with a material with a lower conductivity and higher thickness).

In processing 1 , the external temperature reached $320-330^{\circ} \mathrm{C}$, with very high thermal dispersion, which led to lower internal temperatures and, consequently, a slightly delay in the combustion processes through the kiln.

\section{Conclusions}

The model described in this article calculates some of the most important parameters of the combustion process in a rotary kiln. The simulations were carried out using the operational conditions of a real incineration plant as a reference point. The mass and thermal balances, based on simplified assumptions, were taken into account, together with the kinetic parameters, for the combustion of the specific waste stream. The mass balance considered only the major mass components (C, H, O, N and $\mathrm{S}$ ).

The model shows the temperatures profiles inside and outside the kiln. The temperatures in the last part of the kiln reached $920-930^{\circ} \mathrm{C}$, while the external temperatures were around $200^{\circ} \mathrm{C}$. The model can also be used to check the behaviour of the plant with different boundary conditions. The behaviour with different input flow rates, excess air ratios, and refractory and insulator properties and thicknesses were analysed. The model shows how different waste input flow rates can be used ( $\pm 25 \%$ of the nominal value) in the kiln, without any problems of respecting the temperature limits, set by law, on the complete waste combustion.

Another variable that can optimise combustion is the excess air ratio. This parameter can be changed to obtain the highest energy recovery and, at the same time, to ensure complete waste combustion without the formation of $\mathrm{CO}$ and other related compounds due to incomplete combustion.

Changes in the refractory properties and thicknesses only influence the internal and external kiln temperatures slightly, delaying the combustion processes. Good quality refractory and insulation materials can ensure lower thermal dispersion, obtaining a higher energy recovery; poorer quality refractory materials can be used if, for specific reasons (higher corrosion, fast refractory consumption and/or thermal stress), the combustion chamber temperature has to be decreased in order to avoid excessive temperatures in some parts of the kiln.

\section{Funding}

This research received no specific grant from any funding agency in the public, commercial or not-for-profit sectors. 

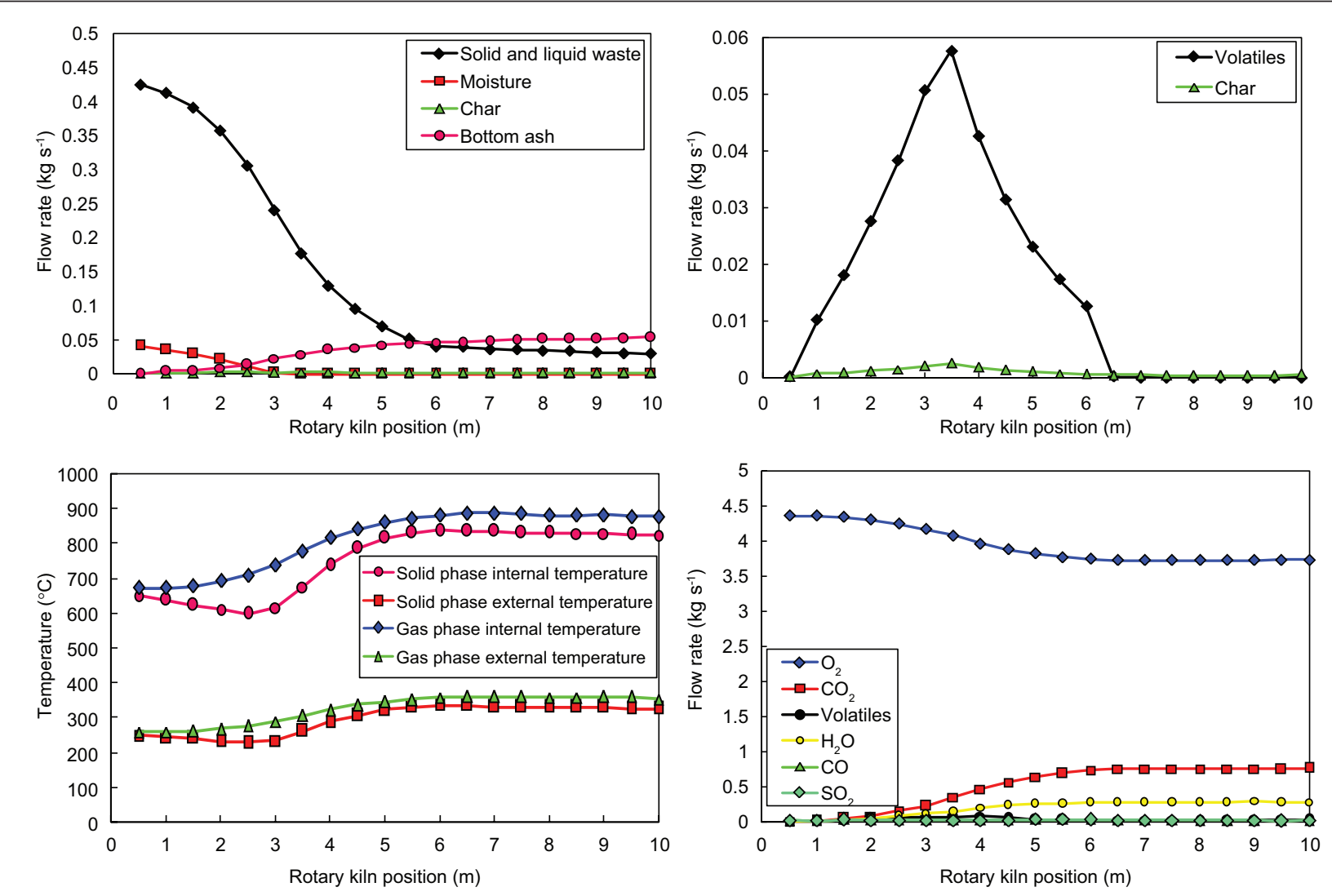

Figure 10. Processing 1. $\mathrm{O}_{2}$ : oxygen; $\mathrm{CO}_{2}$ : carbon dioxide; $\mathrm{H}_{2} \mathrm{O}$ : water; $\mathrm{CO}$ : carbon monoxide; $\mathrm{SO}_{2}$ : sulphur dioxide.

\section{References}

Amutha Rani D, Boccaccini AR, Deegan D and Cheeseman CR (2008) Air pollution control residues from waste incineration: Current UK situation and assessment of alternative technologies. Waste Management 28: 2279-2292.

Boateng AA and Barr PV (1996) A thermal model for the rotary kiln including heat transfer within the bed. International Journal of Heat and Mass Transfer 39: 2131-2147.

Chan WR, Kelbon M and Krieger BB (1985) Modelling and experimental verification of chemical processes during pyrolysis of a large biomass particle. Fuel 64: 1505-1513

Di Blasi C (1998) Comparison of semi-global mechanism for primary pyrolysis of lignocellulosic fuels. Journal of Analytical and Applied Pyrolysis 47: 43-64.

Di Mauro C, Bouchon S and Torretta V (2012) Industrial risk in the Lombardy region (Italy): What people perceive and what are the gaps to improve the risk communication and the participatory processes. Chemical Engineering Transactions 26: 297-302.

Fjellerup J, Ahrenfeldt J and Henriksen U (2005) Pyrolysis of pine wood, experiments and theory. In: Proceedings of 14th European Conference and Exhibition: Biomass for Energy, Industry, and Climate Protection, Paris, France, 17-21 October 2005, Munich, Germany: WIT. CD-ROM.

Font R, Marcilla A, Verdu E and Devese J (1990) Kinetics of the pyrolysis of almond shells and almond shells impregnated with COCL2 in a fluidizedbed reactor and in a pyroprobe 100. Industrial \& Engineering Chemistry Research 29: 1846-1855.

Huai XL, Xu WL, Qu ZY, Li ZG, Zhang FP, Xiang GM, et al. (2008) Numerical simulation of municipal solid waste combustion in a novel two-stage reciprocating incinerator. Waste Management 28: 15-29.

Kathiravale S, Yunus MNM, Sopian K, Samsuddin AH and Rahman RA (2003) Modelling the heating value of municipal sold waste. Fuel 82: 1119-1125.

Leckner B (1972) Spectral and total emissivity of water vapor and carbon dioxide. Combustion and Flame 19: 33-48.
Marias F (2003) A model of a rotary kiln incinerator including processes occurring within the solid and gaseous phase. Computer \& Chemical Engineering 27: 813-825.

Mujumdar R and Ranada P (2006) Simulation of rotary cement kilns using a one-dimensional model. Chemical Engineering Research \& Design 84: $165-177$.

Ndiaye LG, Caillat S, Chynnayya A, Stiovova K, Gambier D and Baudoin B (2008) Modelling the propagation front pyrolysis of porous media with the presence of a front flame in rotary kiln: preliminary result for dynamic and combustion models. In: Proceedings Venice 2008 Second International Symposium on Energy from Waste and Biomass, Venice, Italy, 17-20 November 2008. Padova, Italy: CISA, Environmental Sanitary Engineering Centre. CD-ROM.

Niessen WR (2010) Combustion and Incineration Processes: Applications in Environmental Engineering. 4th ed. Anfover, Massachussets, USA: CRC Press.

Parkish J, Channiwala SA and Ghosal GK (2005) A correlation for calculating HHV from proximate analysis of solid fuel. Fuel 84: 487-494.

Shin D and Choi S (2000) The combustion of simulated waste particles in a Fixed Bed. Combustion and Flame 121: 167-180.

Sorum L, Gronli MG and Hustad JE (2001) Pyrolysis characteristics and kinetics of municipal solid waste. Fuel 80: 1217-1227.

Thurner F and Mann U (1981) Kinetic investigation of wood pyrolysis. Industrial \& Engineering Chemistry Process Design and Development 20: 482-488.

Torretta V, Ragazzi M, Istrate IA and Rada EC (2013) Management of waste electrical and electronic equipment in two EU countries: A comparison. Waste Management 33: 117-122.

Yang YB, Goh YR, Zakaria R, Nasserzadeh V and Swithenbank J (2002) Mathematical modelling of MSW incineration on a travelling bed. Waste Management 22: 369-380.

Yang YB, Yamauchi H, Nasserzadeh V and Swithenbank J (2003) Effects of fuel devolatilisation on the combustion of wood chips and incineration of municipal solid wastes in a packed bed. Fuel 82 : 2205-2221. 
Appendix 1. Parameter variation for following model elaboration.

\section{Nomenclature}

\begin{tabular}{|c|c|c|c|}
\hline$A^{C}$ & \multicolumn{2}{|c|}{ Kinetic factor for combustion } & $\mathrm{s}^{-1}$ \\
\hline$A^{F}$ & \multicolumn{2}{|c|}{ Kinetic factor for formation } & $\mathrm{s}^{-1}$ \\
\hline A & \multicolumn{2}{|c|}{ Surface for the radiation exchange } & $m^{2}$ \\
\hline $\mathrm{C}_{\%}$ & \multicolumn{2}{|c|}{ Contact surface with the indicated phase } & - \\
\hline $\mathrm{C}_{\mathrm{S}}$ & \multicolumn{2}{|c|}{ Contact circumference with the solid phase } & $\mathrm{m}$ \\
\hline $\mathrm{C}_{\mathrm{w}, \mathrm{g}}$ & \multicolumn{2}{|c|}{ Moisture concentration in the gas phase } & $\mathrm{kg} \mathrm{m}^{-3}$ \\
\hline $\mathrm{C}_{\mathrm{w}, \mathrm{s}}$ & \multicolumn{2}{|c|}{ Moisture concentration at the solid surface } & $\mathrm{kg} \mathrm{m}^{-3}$ \\
\hline$\Delta \mathrm{H}_{\mathrm{EV}} \mathrm{LAT}^{\mathrm{LAT}}$ & \multicolumn{2}{|c|}{ Water evaporation enthalpy } & $\mathrm{kJ} \mathrm{kg}^{-1}$ \\
\hline$\Delta \dot{M}_{M O I S T}$ & \multicolumn{2}{|c|}{ Waste water content } & $\mathrm{kg} \mathrm{s}^{-1}$ \\
\hline$\Delta \mathrm{x}$ & \multicolumn{2}{|c|}{ Length of the elementary volume } & $\mathrm{m}$ \\
\hline$E^{C}$ & \multicolumn{2}{|c|}{ Activation energy for combustion } & $\mathrm{kJ} \mathrm{Kmol}^{-1}$ \\
\hline$E^{F}$ & \multicolumn{2}{|c|}{ Activation energy for formation } & $\mathrm{kJ} \mathrm{Kmol}^{-1}$ \\
\hline $\mathrm{F}$ & \multicolumn{2}{|c|}{ View factor } & - \\
\hline$h_{E S T}$ & \multicolumn{2}{|c|}{ External wall conductance } & $\mathrm{W} \mathrm{m}^{-2} \mathrm{~K}^{-1}$ \\
\hline $\mathrm{H}$ & \multicolumn{2}{|c|}{ Convection coefficient } & $\mathrm{W} \mathrm{m}^{-2} \mathrm{~K}^{-1}$ \\
\hline$k_{f}$ & \multicolumn{2}{|c|}{ Conductivity of the fluid } & $\mathrm{W} \mathrm{m}^{-2} \mathrm{~K}^{-1}$ \\
\hline $\mathrm{K}_{\text {is }}$ & \multicolumn{2}{|c|}{ Thermal conductivity of the insulator material } & $\mathrm{W} \mathrm{m}^{-1} \mathrm{~K}^{-1}$ \\
\hline $\mathrm{K}_{\mathrm{m}}$ & \multicolumn{2}{|c|}{ Mass transfer coefficient for char combustion } & $\mathrm{m} \mathrm{s}^{-1}$ \\
\hline $\mathrm{K}_{\mathrm{r}}$ & \multicolumn{2}{|c|}{ Kinetic constant for char combustion } & $\mathrm{m} \mathrm{s}^{-1}$ \\
\hline $\mathrm{K}_{\mathrm{RAD}}$ & \multicolumn{2}{|c|}{ Radiant conductivity } & $\mathrm{W} \mathrm{m}^{-1} \mathrm{~K}^{-1}$ \\
\hline $\mathrm{K}_{\mathrm{re}}$ & Thermal conductivity & material & $\mathrm{W} \mathrm{m}^{-1} \mathrm{~K}^{-1}$ \\
\hline $\mathrm{Kv}$ & Internal conductivity & & $\mathrm{W} \mathrm{m}^{-1} \mathrm{~K}^{-1}$ \\
\hline L & Characteristic length & hange & $\mathrm{m}$ \\
\hline$L_{i, j}$ & Average distance bet & & $\mathrm{m}$ \\
\hline$M_{\mathrm{RIF}}$ & Waste flow rate & & $\mathrm{kg}$ \\
\hline $\mathrm{Nu}$ & Nusselt number & & - \\
\hline $\mathrm{P}$ & Pressure in the comb & & $\mathrm{Pa}$ \\
\hline$\dot{Q}_{C O N V}$ & Convection heat exch & & W \\
\hline$Q_{E V}$ & Evaporation heat & & $\mathrm{kJ} \mathrm{s}^{-1}$ \\
\hline$\dot{Q}_{P, G}$ & Conduction heat exch & he walls and the gas phase & W \\
\hline$\dot{Q}_{P, S}$ & Conduction heat exch & he walls and the solid phase & W \\
\hline$Q_{\text {rad_long_gas_gas }}$ & Longitudinal radiatior & veen gas phase volumes & W \\
\hline$Q_{\text {rad_long_gas_sol }}$ & Longitudinal radiatior & veen gas-solid phase vol. & W \\
\hline$Q_{\text {rad_sol_gas }}$ & Transversal radiation & een gas and solid phases & W \\
\hline$Q_{t_{\text {_sp }}}$ & Transversal radiation & en wall and solid phase & W \\
\hline$r_{\text {kiln }}$ & Internal radius of the & & $\mathrm{m}$ \\
\hline$r_{1}$ & External radius of the & & $\mathrm{m}$ \\
\hline$r_{2}$ & Radius of the insulatc & & $\mathrm{m}$ \\
\hline$r_{3}$ & Radius of the refractc & & $\mathrm{m}$ \\
\hline $\mathrm{R}_{\mathrm{D}}$ & Combustion rate & & $\mathrm{kg} \mathrm{s}^{-1}$ \\
\hline $\mathrm{R}_{\mathrm{F}}$ & Formation rate & & $\mathrm{kg} \mathrm{s}^{-1}$ \\
\hline $\mathrm{R}^{\mathrm{POT}}{ }_{\mathrm{EV}}$ & Potential evaporation & & $\mathrm{kg} \mathrm{s}^{-1}$ \\
\hline $\mathrm{S}$ & Surface that contribu & eat exchange & $m^{2}$ \\
\hline $\mathrm{S}_{\mathrm{a}}$ & Particle surface area & & $m^{2}$ \\
\hline $\mathrm{S}_{\text {CONV }}$ & Separation surface be & gas phases & $\mathrm{m}$ \\
\hline $\mathrm{T}$ & Temperature & & K \\
\hline Greek letters & & & \\
\hline$\alpha$ & Solid absorbance & $\zeta$ & $\begin{array}{l}\text { Correction factor } \\
\text { for char combustion }\end{array}$ \\
\hline$\varepsilon$ & Gas phase emissivity & $\eta_{\mathrm{SOL}}$ & $\begin{array}{l}\text { Solid phase } \\
\text { emissivity }\end{array}$ \\
\hline$\phi$ & Filling coefficient in $t$ & & \\
\hline Subscripts & & & \\
\hline CHAR & Char & S, Sol & Solid phase \\
\hline $\mathrm{CO}$ & Carbon monoxide & VOL & Volatiles \\
\hline Ext & External ambient air & Wal & Kiln walls \\
\hline G, Gas & Gas phase & & \\
\hline
\end{tabular}

